\title{
Concentrations of cadmium and selected essential elements in malignant large intestine tissue
}

\author{
Michał Klimczak ${ }^{1}$, Adam Dziki ${ }^{2}$, Anna Kilanowicz ${ }^{1}$, Andrzej Sapota ${ }^{1}$, Joanna Duda-Szymańska ${ }^{3}$, Adam Daragó ${ }^{1}$ \\ ${ }^{1}$ Department of Toxicology, Medical University of Lodz, Lodz, Poland \\ 2Department of General and Colorectal Surgery, Medical University of Lodz, Lodz, Poland \\ ${ }^{3}$ Department of Pathology, Medical University of Lodz, Lodz, Poland
}

Prz Gastroenterol 2016; 11 (1): 24-29

DOI: $10.5114 / p g .2015 .52563$

Key words: large intestine, colorectal cancer, cadmium, essential elements.

Address for correspondence: Michat Klimczak, Department of Toxicology, Medical University of Lodz, 1 Muszyńskiego St, 90-151 Lodz, Poland, phone: +48 4267791 47, fax: +48 4267791 48, e-mail: michal.klimczak@umed.lodz.pl

\begin{abstract}
Introduction: Colorectal cancer is one of the most common cancers worldwide. Incidence rates of large intestine cancer indicate a role of environmental and occupational factors. The role of essential elements and their interaction with toxic metals can contribute to the explanation of a complex mechanism by which large intestine cancer develops. Bearing this in mind, determining the levels of essential and toxic elements in tissues (organs), as well as in body fluids, seems to shed light on their role in the mode of action in malignant disease.

Aim: Determination of the levels of cadmium, zinc, copper, selenium, calcium, magnesium, and iron in large intestine malignant tissue.

Material and methods: Two intraoperative intestine sections were investigated: one from the malignant tissue and the other one from the normal tissue, collected from each person with diagnosed large intestine cancer. Cadmium, zinc, copper, calcium, magnesium, and iron levels were determined with atomic absorption spectrometry, and selenium levels by spectrofluorimetric method.

Results: The levels of copper, selenium, and magnesium were higher in the malignant than in normal tissues. In addition, the zinc/copper and calcium/magnesium relationship was altered in malignant tissue, where correlations were lower compared to non-malignant tissue.

Conclusions: The results seems to demonstrate disturbed homeostasis of some essential elements. However, it is hard to confirm their involvement in the aetiology of colorectal cancer.

\section{Introduction}

Colorectal cancer is the fourth most common cancer in men and the third most common cancer in women, worldwide. The highest incidence rates are recorded in Europe, North America, and Oceania, and the lowest in South America, Africa, and Asia (e.g. about 4 cases per 100000 population in India), although select registries in Asia (i.e. Japan, Singapore, and Israel) also record high rates. The great variation in the incidence rates of large intestine cancer observed in different parts of the world indicates a significant role of environmental factors (e.g. diet, physical activity) and so-called "western-style living" [1]. Modification of risk factors, primarily by promoting a well balanced diet, regular physical activity, and maintenance of normal body mass, can re-

duce cancer incidence by as much as $50-75 \%$ [2]. It has been also discussed whether occupational factors are responsible for increased risk of colon cancer. A higher risk of colorectal cancer has been reported alter alia among workers exposed to asbestos or wood dust, or those working in the textile industry. Moreover, some pesticides have also been associated with excess risk of colon cancer among pesticide applicators [3].

Large intestine cancer is the final stage of a dynamic process of dysplastic transformation, occurring most frequently in adenoma. Most colon cancers probably arise from benign neoplastic polyps [4]. In large intestine cancer, like in other cancers, early diagnosis and adequate therapeutic procedures provide a good chance of complete recovery. According to the literature data, an early diagnosis can ensure a large proportion of re-
\end{abstract}


covery, reaching as much as $90 \%$. However, the chance of recovery diminishes proportionally to cancer progression. It should be noted that its detection in the most advanced state of malignancy limits 5-year survival to $5 \%[5]$.

Growing interest in concentrations of essential elements (e.g. magnesium (Mg), calcium (Ca), copper (Cu), zinc ( $\mathrm{Zn})$, iron (Fe), and selenium (Se)) in normal and malignant tissues and differences in their distribution have been observed for a number of years. Numerous reports stress the importance of determining serum copper and zinc levels in assessing activity and prognosis of the disease. Some studies have shown increased serum copper and decreased serum zinc levels in patients with sarcoma, lung cancer, and carcinoma of the digestive organs $[6,7]$. However, the mechanisms by which the level of these elements decreases and increases in various cancerous conditions, as well as the issue of whether the altered serum copper and zinc levels are causative factors of the malignant state or its sequel, have not yet been elucidated. Nevertheless, it is obvious that in their attempts to identify possible causes of cancers and thus to facilitate their early diagnosis, researchers also try to analyse the role played by the elements in neoplastic processes.

Reports on the role of essential and toxic elements in the aetiology of large intestine cancer are rather scarce in the literature available to date. The role of copper and its metabolism in the human body has been the subject of much interest among numerous researchers. Its significant involvement in the synthesis of the connective tissue and haemoglobin, and in the normal functioning of the peripheral nervous system has already been evidenced. Tissue and plasma copper levels differ considerably depending on the place of residence, and thus on their content in the diet [8].

Zinc is an activator of several hundred enzymes participating, among others, in RNA replication and DNA repair. $Z n$ deficiency impairs cellular and humoral immunity, and also limits the cytokine production [9]. Zn has also been recognised as an antioxidant. An effective anti-oxidative defence depends greatly on the regular metabolism of essential elements; therefore, it is not surprising that a great body of studies have been focused on their role in the development of carcinomas and large intestine adenocarcinoma. In the experimental adenocarcinoma, selenium stimulates DNA repair [10]. The protective role of Se in cancer is supported also by clinical and epidemiological studies [11], where an inverse association between Se supplementation and the risk of colorectal cancer was observed [12].

Epidemiological studies have demonstrated an association between the risk of colon cancer and low intake of $\mathrm{Mg}$. Moreover, a diet rich in $\mathrm{Mg}$ was found to reduce the occurrence of this cancer. Animal studies established that $\mathrm{Mg}$ could be a protective agent in the early stages of carcinogenesis. Nevertheless, it could also promote the growth of existing malignancies at later stages $[13,14]$. It has been shown that $\mathrm{Ca}, \mathrm{Zn}$, and $\mathrm{Cu}$ can also reduce the risk of colon and rectum cancers [15].

Cadmium is one of the known factors responsible for the disturbed homeostasis of essential metals. According to Elinder et al., cadmium, along with nephrotoxic and carcinogenic (lung cancer) effects, induces changes in $\mathrm{Zn}, \mathrm{Cu}, \mathrm{Fe}, \mathrm{Mg}, \mathrm{Ca}$, and Se interaction-based distribution, which can be manifested by the deficiency of these compounds in individual tissues, diminished haematological indices (iron, haemoglobin, haematocrit), disturbed metabolism of carbohydrates (decreased insulin secretion), and induced lipid peroxidation [16].

To be able to shed more light on the role of essential elements in their mode of action in malignant disease, the content of each element in the tumour tissue itself should be determined. Apparently the identification of the role of elements and their interaction with toxic metals (cadmium) can significantly contribute to the explanation of a complex mechanism by which inter alia large intestine cancer develops.

\section{Aim}

In view of the limited data available to date, the need to carry out studies aimed at determining the levels of metals and essential and toxic elements in tissues (organs) and body fluids seems to be well founded, so the aim of this study was to determine the levels of cadmium, zinc, copper, selenium, calcium, magnesium, and iron in intraoperative sections of large intestine malignant tissues and in normal tissues taken as the control.

\section{Material and methods}

The study was carried out in a group of 25 persons (16 men and 9 women) with diagnosed large intestine cancer (Adenocarcinoma mucinosum). Two intraoperative intestine sections, one from the malignant tissue and the other from normal tissue, located at a maximum distance from the focus of malignancy, were collected from each person. All of the tissues were examined morphologically to confirm the diagnosis. The samples were stored in polyurethane containers at $-70^{\circ} \mathrm{C}$ until examination. None of the patients from whom the tissues were collected had previously been subjected to radiotherapy or bio-element supplementation. All of the patients were matched for age and cancer progression, had not been occupationally exposed 
Table I. Cadmium (Cd), zinc (Zn), copper (Cu), selenium $(\mathrm{Se})$, magnesium $(\mathrm{Mg})$, calcium $(\mathrm{Ca})$, and iron (Fe) concentrations (mean $\pm \mathrm{SD} ; \mu \mathrm{g} / \mathrm{g}$ wet tissue) in normal and malignant tissues of large intestine

\begin{tabular}{lcc} 
Element & Malignant tissue & Normal tissue \\
\hline $\mathrm{Cd}$ & $0.04 \pm 0.03$ & $0.04 \pm 0.02$ \\
\hline $\mathrm{Zn}$ & $17.50 \pm 5.40$ & $15.35 \pm 6.30$ \\
\hline $\mathrm{Cu}$ & $1.10 \pm 0.57^{\star}$ & $0.64 \pm 0.39$ \\
\hline $\mathrm{Se}$ & $0.12 \pm 0.07^{\star}$ & $0.05 \pm 0.03$ \\
\hline $\mathrm{Mg}$ & $76.78 \pm 31.41^{\star}$ & $43.81 \pm 18.91$ \\
\hline $\mathrm{Ca}$ & $58.53 \pm 9.25$ & $47.94 \pm 13.18$ \\
\hline $\mathrm{Fe}$ & $31.92 \pm 15.18$ & $34.06 \pm 11.56$
\end{tabular}

*Statistically significant difference $(p<0.05)$.

to heavy metals, and were non-smokers. This study was approved by the Ethics Committee for Scientific Research at the Medical University in Lodz (Resolution No RNN/156/02/KE).

Cadmium levels were determined with graphite furnace absorption spectrometry (HITACHI Z8270), and zinc, copper, calcium, magnesium, and iron levels with flame atomic absorption spectrometry (GBC Avanta PM) following mineralisation. Selenium levels were determined using the spectrofluorimetric method (HITACH F4500) [17].

The limits of detection, calculated as concentrations corresponding with the value of absorption equal to a threefold standard deviation of the signal for the lowest standard, were respectively $0.001 \mu \mathrm{g} / \mathrm{ml}$ for cadmium, $0.02 \mu \mathrm{g} / \mathrm{ml}$ for zinc, $0.02 \mu \mathrm{g} / \mathrm{ml}$ for copper, $0.15 \mu \mathrm{g} / \mathrm{ml}$ for selenium, $0.01 \mu \mathrm{g} / \mathrm{ml}$ for calcium, $0.01 \mu \mathrm{g} / \mathrm{ml}$ for magnesium, and $0.01 \mu \mathrm{g} / \mathrm{ml}$ for iron.

The intra-laboratory quality control was based on reference material SRM $1577 \mathrm{~b}$ - lyophilised bovine liver

A

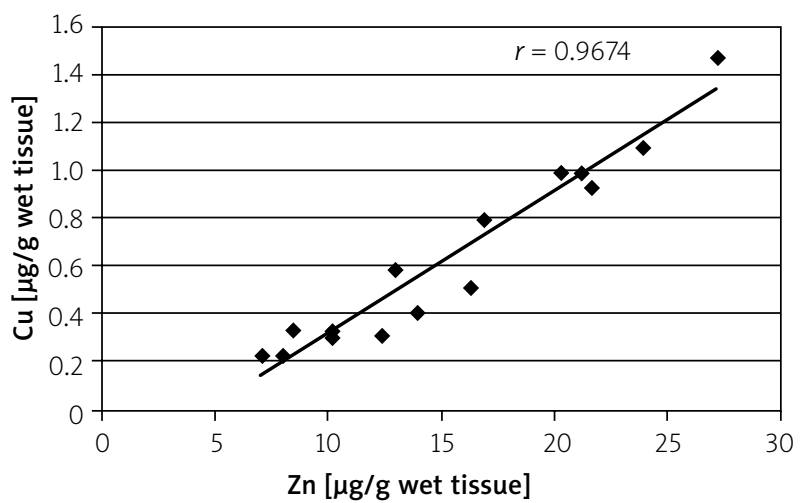

(National Institute of Standards \& Technology, Gaithersburg, Germany), with certified measurements of the following elements $[\mu \mathrm{g} / \mathrm{g}]$ : Cd $(0.5 \pm 0.03), \mathrm{Zn}(127$ $\pm 16), \mathrm{Cu}(160 \pm 8)$, Se (0.73 \pm 0.06$), \mathrm{Ca}(116 \pm 4), \mathrm{Mg}$ (601 $\pm 28)$, and Fe (184 \pm 15$)$. Mean discrepancies between the obtained results, compared with certified values expressed as RSD, were: $\mathrm{Cd} \pm 2.1 \%, \mathrm{Zn} \pm 0.3 \%$, Cu $\pm 8.3 \%$, $\mathrm{Se} \pm 3.5 \%, \mathrm{Ca} \pm 6.7 \%, \mathrm{Mg} \pm 7.2 \%$, and $\mathrm{Fe} \pm 5.8 \%$. The error of repeatability did not exceed $10 \%$ in any of the study samples.

\section{Results}

The results of the study are presented in Table I. The concentration of selenium in malignant tissue was more than two times higher than in normal tissue, and this was the highest statistically significant difference in our study. Levels of copper and magnesium were also significantly higher in malignant tissue - respectively, $170 \%$ and $180 \%$ of value determined in normal tissue. Cancerous transformation does not seem to affect zinc, calcium, cadmium, and iron levels, which were similar in malignant and non-malignant tissue.

The determined values of elements were also analysed in terms of their interrelations and correlations. On the basis of adequate calculations, a high correlation (almost 1) was observed between $\mathrm{Zn}$ and Cu concentrations in the normal tissue, but it was disturbed in the malignant tissue, where it was much lower (Figure 1). Similarly large differences between correlations were noted between $\mathrm{Ca}$ and $\mathrm{Mg}$ concentrations. Although the correlation between these elements in normal tissue was moderate; in the malignant tissue there seemed to be no relationship at all (Figure 2).

\section{Discussion}

The majority of published literature data focus on the determination of essential elements in blood se-

B

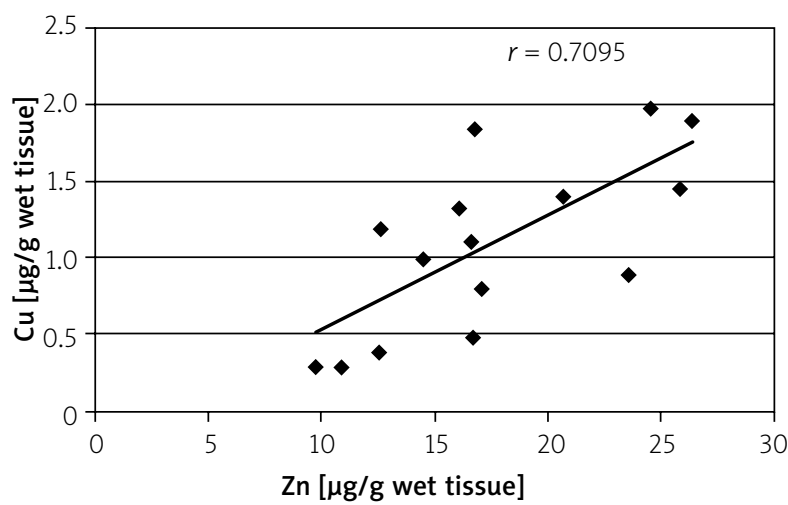

Figure 1. Correlation between zinc $(\mathrm{Zn})$ and copper $(\mathrm{Cu})$ concentrations in normal (A) and malignant (B) tissues of large intestine 
A

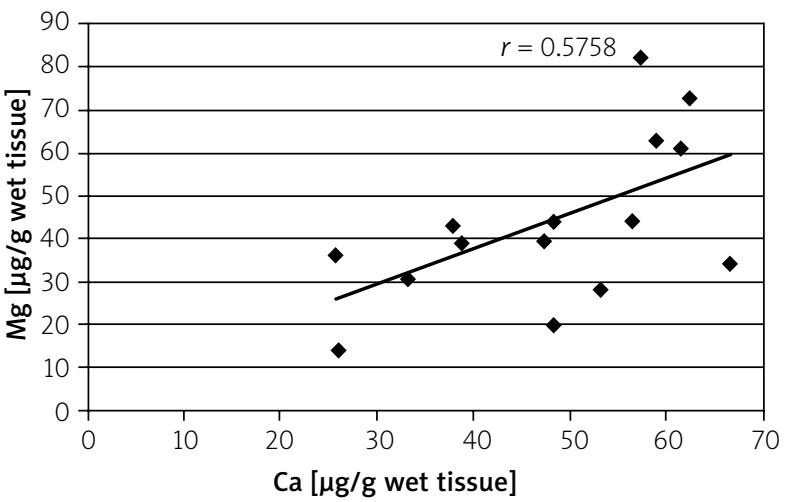

B

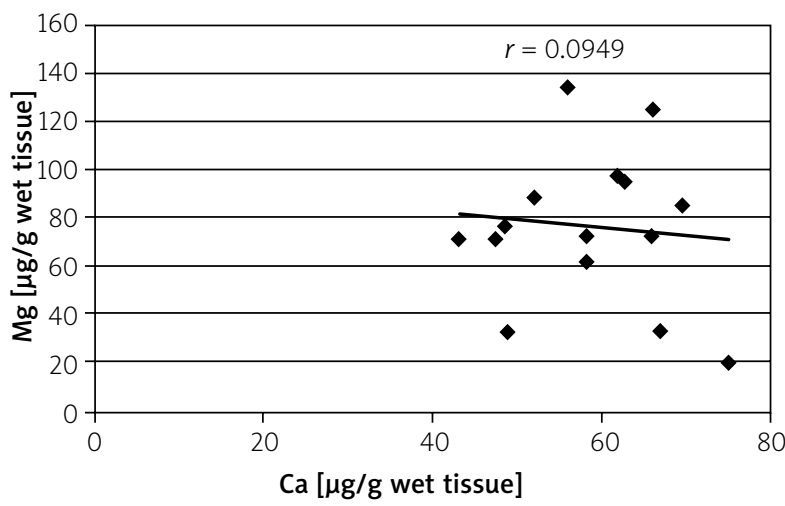

Figure 2. Correlation between calcium (Ca) and magnesium (Mg) concentrations in normal (A) and malignant (B) tissues of large intestine

rum to identify a biomarker useful in early detection of malignant pathologies. Studies carried out to observe changes in concentrations of these elements in organs and tissues already affected by neoplastic lesions are less numerous. It is well known that the observed alterations in element concentrations in blood serum result, among others, from changes in homeostasis of essential elements in malignant tissues.

The literature data published in the last decade indicate that disturbed levels of elements, mostly zinc and copper, can play a significant role in the mechanism responsible for uncontrolled cellular growth. It is thought that $\mathrm{Cu}$ plays an essential role in the activation of endothelium cells by stimulating angiogenic growth factors, which results in stimulation of the proliferation process [18]. Copper involvement in the carcinogenic process may also be linked to its ability to bind to some proteins, thus stimulating their angiogenic activity. This can explain the fact that in a number of cancers even a several-fold increase in Cu level in serum and malignant tissues was observed (in our study almost twofold), whereas others do not confirm this observation, especially according to tissue levels [19, 20]. Due to long-term monitoring of serum Cu concentration, it is feasible that the absence of changes in its concentration for a long period of time indicates a very good prognosis, whereas the increase in its concentration may show the recurrence of the carcinogenic process.

Zinc plays an important role in the carcinogenic process as it takes part in each stage of cellular cycle, regulation, and expression of genes as well as in DNA synthesis. Numerous authors have shown in in vitro studies that Zn exerts anti-proliferating and pro-apoptotic effects inter alia in prostate gland cells [21]. It is also suggested that the protective effect of $Z n$ results from its competing with other essential elements, mainly $\mathrm{Cu}$ and Fe. Based on the literature, it is also well known that the blood serum Zn concentration undergoes changes in the state of increased metabolic activity of the organism. A diminished Zn concentration is observed in cancers of different sites. The progression of neoplastic transformation is linked with decreasing Zn concentration in serum [22].

Numerous publications provide evidence that Se compounds are characterised by anticancer properties. Se may act in cancer prevention via numerous mechanisms and on all stages of cancer progression [11]. It has been found that Se induces apoptosis in malignant tissues [23]. An increased Se concentration in malignant tissues may point to the body's immune reaction and its attempt to induce apoptosis in aplastic cells through increasing the number of free radicals and thus enhancing oxidative stress. The mechanism by which free radicals are produced, and the results from this oxidative stress induced by selenium, is favourable to the body on the one hand, in view of anticancer effect, and unfavourable on the other as an Se toxic effect cannot be ruled out [24].

Unbalanced Mg homeostasis is often noticed in malignant cells, which accumulate this element, behaving like a magnesium trap. Moreover, high affinity of neoplastic cells for Mg was also observed in cell cultures with low Mg concentration [13].

The results of our study partly confirm observations of other researchers (Tables II and III), who found increased $\mathrm{Cu}$ levels in the large intestine malignant tissues. The same concerns $\mathrm{Zn}$, levels of which are often only slightly departed from those found in normal tissue $[6,19,25-28]$. The observed inconsistency in element levels both in normal and malignant tissue are difficult to elucidate. It may be influenced by many factors, e.g. diet, different determination methods, and differences in the end outcomes ( $\mu \mathrm{g} / \mathrm{g}$ dry or wet tissue). 
Table II. Zinc (Zn), copper (Cu), and selenium (Se) concentrations (mean \pm SD; $\mu$ g/g wet tissue) in malignant and normal tissues of the large intestine according to different authors

\begin{tabular}{|c|c|c|c|c|c|c|}
\hline \multirow[t]{2}{*}{ Authors, methods } & \multicolumn{2}{|c|}{$\mathrm{Zn}$} & \multicolumn{2}{|c|}{$\mathrm{Cu}$} & \multicolumn{2}{|c|}{ Se } \\
\hline & $\begin{array}{l}\text { Malignant } \\
\text { tissue }\end{array}$ & $\begin{array}{l}\text { Normal } \\
\text { tissue }\end{array}$ & $\begin{array}{l}\text { Malignant } \\
\text { tissue }\end{array}$ & $\begin{array}{l}\text { Normal } \\
\text { tissue }\end{array}$ & $\begin{array}{l}\text { Malignant } \\
\text { tissue }\end{array}$ & $\begin{array}{l}\text { Normal } \\
\text { tissue }\end{array}$ \\
\hline Margalioth et al., 1983 [6], AAS & $18.6 \pm 6.34$ & $18.3 \pm 3.8$ & $1.90 \pm 0.6$ & $1.53 \pm 0.35$ & - & - \\
\hline Gregoriadis et al., 1983 [25], PIXRF & $14.3 \pm 2.7$ & $15.2 \pm 3.1$ & $1.70 \pm 0.64$ & $1.34 \pm 0.33$ & - & - \\
\hline $\begin{array}{l}\text { Drake and Sky-Peck, } 1989 \text { [19], } \\
\text { ultramicroEDXRF }\end{array}$ & $98.2 \pm 18.7$ & $64.1 \pm 20.5$ & $8.9 \pm 3.4$ & $14.1 \pm 4.4$ & $1.26 \pm 0.28$ & $1.53 \pm 0.33$ \\
\hline Witkowski et al., 1993 [26], AAS & - & - & $5.18 \pm 2.63$ & $5.76 \pm 1.54$ & - & - \\
\hline Arriola et al., 1999 [29], INNA & $8.08 \pm 0.60$ & $7.53 \pm 0.50$ & $0.27 \pm 0.04$ & $0.40 \pm 0.06$ & $1.54 \pm 0.25$ & $1.31 \pm 0.20$ \\
\hline Kucharzewski et al., 2003 [27], TRXRF & $14.80 \pm 0.82$ & - & $3.87 \pm 0.27$ & - & $0.86 \pm 0.19$ & - \\
\hline Daragó et al., 2005 [28], AAS & $17.44 \pm 5.60$ & $15.54 \pm 6.73$ & $1.09 \pm 0.63$ & $0.64 \pm 0.42$ & $0.12 \pm 0.07$ & $0.05 \pm 0.03$ \\
\hline Milde et al., 2005 [30], AAS & $69.20 \pm 21.03$ & - & $6.08 \pm 3.78$ & - & $1.17 \pm 0.73$ & - \\
\hline Majewska et al., 2007 [4], TXRF & $14.8 \pm 9.63$ & - & $3.55 \pm 2.36$ & - & $0.816 \pm 0.557$ & - \\
\hline Lavilla et al., 2009 [31], ICP-OES, ICP-MS & 89 & 79 & 8.5 & 6.2 & 1.6 & 0.9 \\
\hline Szewczyk et al., 2013 [7], AAS & $1.61 \pm 0.93^{*}$ & $3.22 \pm 1.91^{\star}$ & $10.3 \pm 3.0^{*}$ & $6.3 \pm 1.8^{*}$ & - & - \\
\hline
\end{tabular}

Table III. Calcium (Ca), iron (Fe), cadmium (Cd), and magnesium (Mg) concentrations (mean \pm SD; $\mu$ g/g wet tissue) in malignant and normal tissues of the large intestine according to different authors

\begin{tabular}{|c|c|c|c|c|c|c|c|c|}
\hline \multirow[t]{2}{*}{ Authors, methods } & \multicolumn{2}{|c|}{$\mathrm{Fe}$} & \multicolumn{2}{|c|}{$\mathrm{Mg}$} & \multicolumn{2}{|c|}{$\mathrm{Ca}$} & \multicolumn{2}{|c|}{$\mathrm{Cd}$} \\
\hline & $\begin{array}{l}\text { Malignant } \\
\text { tissue }\end{array}$ & $\begin{array}{l}\text { Normal } \\
\text { tissue }\end{array}$ & $\begin{array}{l}\text { Malignant } \\
\text { tissue }\end{array}$ & $\begin{array}{l}\text { Normal } \\
\text { tissue }\end{array}$ & $\begin{array}{l}\text { Malignant } \\
\text { tissue }\end{array}$ & $\begin{array}{l}\text { Normal } \\
\text { tissue }\end{array}$ & $\begin{array}{l}\text { Malignant } \\
\text { tissue }\end{array}$ & $\begin{array}{l}\text { Normal } \\
\text { tissue }\end{array}$ \\
\hline $\begin{array}{l}\text { Drake and } \\
\text { Sky-Peck, } 1989 \text { [19], } \\
\text { ultramicroEDXRF }\end{array}$ & $129 \pm 41.2$ & $189 \pm 50.5$ & - & - & $393 \pm 195$ & $591 \pm 253$ & - & - \\
\hline $\begin{array}{l}\text { Arriola et al., } 1999 \\
\text { [29], INNA }\end{array}$ & $120.24 \pm 4.09$ & $131.45 \pm 4.21$ & $20.96 \pm 0.82$ & $19.76 \pm 0.73$ & $9.07 \pm 0.83$ & $11.18 \pm 0.93$ & - & - \\
\hline $\begin{array}{l}\text { Kucharzewski et al., } \\
2003 \text { [32], TRXRF }\end{array}$ & $46.1 \pm 4.27$ & - & - & - & - & - & - & - \\
\hline $\begin{array}{l}\text { Milde et al., } 2005 \\
\text { [30], AAS }\end{array}$ & - & - & $\begin{array}{r}753.59 \\
\pm 310.54\end{array}$ & - & - & - & - & - \\
\hline $\begin{array}{l}\text { Daragó et al., } 2005 \\
\text { [28], AAS }\end{array}$ & - & - & - & - & - & - & $0.04 \pm 0.02$ & $0.04 \pm 0.02$ \\
\hline $\begin{array}{l}\text { Majewska et al., } \\
2007 \text { [4], TXRF }\end{array}$ & $45.00 \pm 33.40$ & - & - & - & - & - & - & - \\
\hline $\begin{array}{l}\text { Szewczyk et al., } \\
2009 \text { [20], } \\
\text { colorimetrically }\end{array}$ & - & - & $6.77 \pm 2.4$ & $6.40 \pm 1.7$ & - & - & - & - \\
\hline $\begin{array}{l}\text { Lavilla et al., } 2009 \\
\text { [31], ICP-OES, } \\
\text { ICP-MS }\end{array}$ & 194 & 125 & 664 & 323 & 1462 & 459 & 0.14 & 0.23 \\
\hline
\end{tabular}

Abbreviations as in Table II. 


\section{Conclusions}

The results of our study seem to demonstrate disturbed homeostasis of some essential elements, mostly $\mathrm{Mg}$ and $\mathrm{Cu}$. However, it is hard to confirm their involvement in the aetiology of colorectal cancer.

\section{Acknowledgments}

This study was sponsored by the Medical University of Lodz, Poland (Grant No. 503-3045-1).

\section{Conflict of interest}

The authors declare no conflict of interest.

\section{References}

1. Center MM, Jemal A, Smith RA, et al. Worldwide variations in colorectal cancer. CA Cancer J Clin 2009; 59: 366-78.

2. Kaleta-Stasiołek D, Kwaśniewska M, Drygas W. Selected risk factors and primary prevention of colorectal cancer [Polish]. Przegl Lek 2002; 60: 170-5.

3. Lee WJ, Sandler DP, Blair A, et al. Pesticide use and colorectal cancer risk in the Agricultural Health Study. Int I Cancer 2007; 121: 339-346.

4. Majewska U, Banaś D, Braziewicz J, et al. Trace element concentration distributions in breast, lung and colon tissues. Phys Med Biol 2007; 52: 3895-911.

5. Lutz JM, Francisci S, Mugno E, et al. Cancer prevalence in Central Europe: the EUROPREVAL Study. Ann Oncol 2003; 14: 313-22.

6. Margalioth EJ, Schenker JG, Chevion M. Copper and zinc levels in normal and malignant tissues. Cancer 1983; 52: 868-72.

7. Szewczyk M, Pasternak K, Andrzejewski A, et al. Plasma and cancerous tissue concentration of $\mathrm{Zn}, \mathrm{Cu}$ and $\mathrm{Mn}$ in patients undergoing surgical treatment for gastrointestinal cancer. J Elem 2013; 18: 135-144.

8. Versieck J, Cornelis R. Normal levels of trace elements in human blood, plasma, or serum. Anal Chim Acta 1980; 116: 217-54.

9. Costello LC, Franklin RB. The intermediary metabolism of the prostate: a key to understanding the pathogenesis and progression of prostate malignancy. Oncology 2000; 59: 269-82.

10. Lawson T. Nicotinamide and selenium stimulate the repair of DNA damage produced by $\mathrm{N}$-nitrosobis (2-oxopropyl) amine. Anticancer Res 1989; 9: 483-86.

11. Hu Y, McIntosh GH, Young GP. Selenium-rich foods: a promising approach to colorectal cancer prevention. Curr Pharm Biotechnol 2012; 13: 165-72.

12. Pericleous M, Mandair D, Caplin ME. Diet and supplements and their impact on colorectal cancer. J Gastrointest Oncol 2013; 4: 409-23.

13. Castiglioni S, Maier JA. Magnesium and cancer: a dangerous liason. Magnes Res 2011; 24: S92-100.

14. Błaszczyk U, Duda-Chodak U. Magnesium: its role in nutrition and carcinogenesis. Rocz Panstw Zakl Hig 2013; 64: 165-71.

15. Ksiądzyna D, Paradowski L. Environmental factors and the etiology of intestinal neoplasm [Polish]. Gastroenterol Pol 2004; 11: 369-74.

16. Elinder CG, Kjellstrom T, Hogstedt C, et al. Cancer mortality of cadmium workers. Br J Ind Med 1985; 42: 651-5.
17. Watkinson JH. Fluorometric determination of selenium in biological material with 2,3-diaminonaphthalene. Anal Chem 1966; 38: 92-7.

18. Brem S, Wotoczek-Obadia MC. Regulation of angiogenesis by copper reduction and penicillamine: antagonism of cytokine and growth factor activity. AACR Special Conference: Angiogenesis and Cancer Research. Orlando, Fla; January 1998; 24-8.

19. Drake EN, Sky-Peck HH. Discriminant analysis of trace element distribution in normal and malignant human tissues. Cancer Res 1989; 49: 4210-5.

20. Szewczyk M, Pasternak K, Andrzejewski A, et al. Magnesium concentration in plasma and tissues of patients undergoing surgery for stomach and large intestine cancer. J Elem 2009; 14: 563-71.

21. Feng P, Liang JY, Li TL, et al. Zinc induces mitochondria apoptogenesis in prostate cells. Mol Urol 2000; 4: 31-6.

22. Sznajda J. The clinical biochemistry in practice medicine [Polish]. PZWL, Warsaw 1983.

23. Behn D, Weiss-Nowak C, Kalcklosch M, et al. Studies on the distribution and characteristics of new mammalian selenium-containing proteins. Analyst 1995; 120: 823-5.

24. Combs GF Jr, Gray WP. Chemopreventive agents: selenium. Pharmacol Ther 1998; 79: 179-92.

25. Gregoriadis GC, Apostolidis NS, Romanos AN, et al. A comparative study of trace elements in normal and cancerous colorectal tissues. Cancer 1983; 52: 508-19.

26. Witkowski K, Kozłowski A, Pardela M, et al. Level of copper in plasma and tissue of patients with esophageal and large bowel cancer [Polish]. Wiad Lek 1993; 46: 586-8.

27. Kucharzewski M, Braziewicz J, Majewska U, et al. Selenium, copper, and zinc concentrations in intestinal cancer tissue and in colon and rectum polyps. Biol Trace Elem Res 2003; 92: 1-10.

28. Daragó A, Rzetecki T, Dziki A, et al. Biological levels of cadmium, zinc, copper and selenium in the patient with colon cancer [Polish]. Bromat Chem Toksykol 2005; 38: 371-6.

29. Arriola H, Longoria L, Quintero A, et al. INAA of trace elements in colorectal cancer patients. Biol Trace Elem Res 1999; 71-72: 563-8.

30. Milde D, Altmannnova K, Vyslouzil K, et al. Trace element levels in blood serum and colon tissue in colorectal cancer. Chem Pap 2005; 59: 157-60.

31. Lavilla I, Costas M, Miguel PS, et al. Elemental fingerprints of timorous and adjacent non-tumorous tissues from patients with colorectal cancer using ICP-MS, ICP-OES and chemometric analysis. Biometals 2009; 22: 863-75.

32. Kucharzewski M, Braziewicz J, Majewska U, et al. Iron concentrations in intestinal cancer tissue and in colon and rectum polyps. Biol Trace Elem Res 2003; 95: 19-28.

Received: 13.12 .2014

Accepted: 11.02.2015 